\title{
Use of Coconut Oil Cake for the Production of $\alpha$ - Amyalse Using Aspergillus oryzae by Solid State Fermentation
}

\author{
${ }^{1}$ B. Shahakar, ${ }^{2}$ A. Rewatkar* \\ ${ }^{1,2}$ Shri. Shivaji Science College, Congres Nagar, Nagpur-440012, Maharashtra, India
}

\begin{abstract}
Modern developments in biotechnology, particularly an area such as protein engineering and directed evolution have provided vital tools for the competent development of new enzymes. Aspergillus oryzae was used in this study for evaluation of its potential for a-amylase production in which coconut oil cake is used which is an agro-industrial residue. The maximum production of amylases was found to be after $72 \mathrm{hr}$ at $30^{\circ} \mathrm{C}$ and enzyme concentration at that point was $11.9 \mathrm{mg} / \mathrm{ml}$ and maximum protein content was $20.1 \mathrm{mg} / \mathrm{ml}$. coconut oil cake possessed good efficiency as a substrate for high yields of $\alpha$-amylase. Microbial enzymes are widely used in industrial processes and $\alpha$-amylase is one of the most important industrial enzymes, having application in industrial processes such as brewing, backing, textile, pharmaceuticals, starch processing, and detergents.
\end{abstract}

Keywords: coconut oil cake, $\alpha$ - amylase, Aspergillus oryzae, solid state fermentation.

\section{Introduction}

Solid state fermentation is generally defined as the growth of microorganisms on solid material in the absence of free water. Solid state fermentation has been used for the production of a wide spectrum of products including enzymes, organic acids, antibiotics, alkaloids, aroma compounds etc. Fermentation including agroindustrial cassava, bagasse, coffee, husk, coconut oil cake, rice bran, sugarcane bagasse, sweet sorghum, tea waste, wheat bran, yam bean ${ }^{[1]}$. Oil meals are bi products obtained after oil extraction from seeds. Oil cakes are of two types, edible and non-edible. Edible oil cakes have a high nutritional value; especially have protein content ranging from 15 to $50 \%{ }^{[2]}$. Due to their rich protein content, they are used as animal feed, especially for ruminants and fish. Coconut oil cake is a bi product obtained after oil extraction from "dried khobra". Coconut oil cake contains starch, soluble sugars, soluble proteins, lipids and trace amount of nitrogen. A potential method to convert coconut oil cake into a value added product such as animal feed supplemented a production of enzyme ${ }^{[3]}$. Enzymes are ubiquitous components of all types of living cells, in plants, animals or microbial growth. Enzymes are physiologically necessary for living organism ${ }^{[4]}$.

$\alpha$-amylases are some of the most versatile enzyme in the industrial enzyme sector and account for approximately $25 \%$ of the enzyme market ${ }^{[5]}$. $\alpha$-amylases (E.C.3.2.1.1.) extracellular enzyme catalyzes the endohydrolysis of 1,4-alpha-D-glycosidic linkages in polysaccharides containing 3 or more 1,4-alpha-linked glucose units. The enzyme acts on starches, glycogen and oligosaccharides in random manner, liberating reducing groups ${ }^{[6]}$. In storage tissue such as seeds, starch, a polysaccharide of glucose is hydrolyzed by growing seedling to meet its energy requirement. The control mechanism involved in formation and secretion of extracellular enzymes, moulds are capable of producing high amounts of amylases; Aspergillus niger is used for the commercial production of $\alpha$-amylases. Solid state fermentation is widely established for the production of enzyme by filamentous fungi ${ }^{[7]}$.

These amylases have high efficiency in saccharification of starch when compared to bacterial $\alpha$ amylases. Aspergillus oryzae has an efficient system for secretion of proteins and is extensively used to produce industrial enzyme ${ }^{[8]}$. The hyphal mode of fungal growth and their good in tolerance to low water activity (aw) and high osmotic pressure conditions make fungi efficient and competitive in natural micro flora for bioconversions of solid substrates ${ }^{[9]}$. Oil cakes are bi products obtained after oil extraction, depending upon the extraction methods the chemical composition of oil cake varies ${ }^{[10]}$. These oil cakes are fairly rich in protein and are traditionally used as feed ingredients for farm animals. They are also used as agriculture feeds ${ }^{[11]}$. Cakes have been used as substrates in SSF for the production of glucoamylase by Aspergillus niger ${ }^{[12]}$, phytase by Rhizopus oligosporus, Lipase by Candida rugosa ${ }^{[13]}$.

Oil cakes are rich in fibre and have high concentration of non-starch polysaccharides (NSP). Aspergillus oryzae has apparently been an essential part of oriental food productions for centuries and is now used in the production of many different oriental foods such as soya sauce, sake and miso.

A. oryzae is a safe well defined aspergillum. When in contact with energy sources Aspergillus oryzae secrete enzymes capable of converting complex organic molecules to simpler ones; A. oryzae is also high in phosphatise activities increasing the bioavailability of phosphate as energy source to increase metabolism in the inoculated microbes those in the surrounding environment ${ }^{[14,15]}$. 


\begin{tabular}{|l|l|}
\hline Ingredients & $\begin{array}{l}\text { In } \\
\text { Percentage }\end{array}$ \\
\hline Dry matter & $92.6 \%$ \\
\hline Crude protein & $49.5 \%$ \\
\hline Crude fiber & $5.3 \%$ \\
\hline Ash & $4.5 \%$ \\
\hline Calcium & $0.11 \%$ \\
\hline Phosphorus & $0.74 \%$ \\
\hline
\end{tabular}

Table no -1: Composition of Oil Cake

\section{Materials and method}

Coconut oil cake, Maltose solution Di-nitro salicylic acid, $\mathrm{NaOH}, \mathrm{NaCl}$, Starch solution, Phosphate Buffer, Bovine serum albumin, Alkaline copper sulphate solution, Folin's reagent, minerals salt solution (2.5gm sodium nitrate, $1 \mathrm{gm}$ dipotasium hydrogen phosphate, $0.5 \mathrm{gm}$ potassium dihydrogen phosphate, $0.5 \mathrm{gm}$ magnesium sulphate, $0.1 \mathrm{gm}$ potassium chloride, $0.01 \mathrm{gm}$ calcium chloride, $0.01 \mathrm{gm}$ ferrous sulphate)

\section{Method:}

\section{Preparation of inoculum:}

$10 \mathrm{ml}$ of distilled water containing $0.1 \%$ Tween 80 was transferred to fully sporulated (7 days old) PDA slant culture. The spores were dislodged using inoculating needle under aseptic conditions. The spore suspension was used as the master suspension was approximately diluted for the required density of spores. $1 \mathrm{ml}$ of the prepared spore suspension was used as the inoculums.

\section{Solid state fermentation}

$5 \mathrm{gm}$ of solid-substrates was weighed into $250 \mathrm{ml}$ of Erlenmeyer flask and to this supplementing salt with $\mathrm{KH}_{2} \mathrm{PO}_{4}, \mathrm{NaNO}_{3}, \mathrm{CaCl}_{2}, \mathrm{MgSO}_{4}, \mathrm{KCl}, \mathrm{K}_{2} \mathrm{HPO}_{4}, \mathrm{FeSO}_{4}$ and distilled water was added to the desired moisture level. The content was sterilized solid substrate it was inoculated with $1 \mathrm{ml}$ of the inoculums. The content were mixed again and incubated at $30^{\circ} \mathrm{C}$ temperature for 48 hour.

\section{Enzyme extraction}

The crude enzyme from the fermented material was extracted by simple contact method. For this, the fermented substrate was mixed thoroughly with distilled water containing $0.1 \%$ of Tween 80 , so that the total extract volume was $100 \mathrm{ml}$ (i.e. if $\mathrm{x} \mathrm{ml}$ of solution was added to make up total volume of $100 \mathrm{ml}$ ). Contents were mixed thoroughly by shaking the flask for $1 \mathrm{hr}$ at $30^{\circ} \mathrm{c}$ on a rotary shaker at $180 \mathrm{rpm}$. At the end of extraction, the suspension was centrifuged at $7000 \mathrm{rpm}$ for $10 \mathrm{~min}$ (C-24 Cooling Centrifuge, REMI) and the supernatant was collected and used as the crude enzyme for analysis.

Enzyme assay was carried out and protein estimation carried out by follin lowry's method.

\section{Effect of incubation time on solid state fermentation:}

To optimize the incubation time, fermentation was carried out by using coconut oil cake having moisture content up to desired level, at $30^{\circ} \mathrm{c}$. Sample was withdrawn every $24 \mathrm{hr}$. and extracted. The extract was assayed for $\alpha$-amylase and soluble protein content.

\section{Effect of incubation temperature on solid state fermentation:}

Solid state fermentation was carried out at different incubation temperature ranging from 20 to $30^{\circ} \mathrm{c}$. the initial moisture content was maintained at desired moisture level and samples extracted after $72 \mathrm{hr}$. the extract was assayed for $\alpha$-amylase and protein content.

\section{Effect of supplementation of starch as additional carbon source on solid state fermentation:}

The effect of supplementation of the substrate with carbon source and studied by supplementing the fermentation medium with varying percentage of soluble starch (1 to 4\%). Solid state fermentation was carried out on the prepared media with an initial moisture of desired level at $30^{\circ} \mathrm{c}$ for $72 \mathrm{hr}$. the sample after fermentation were extracted and assayed for $\alpha$-amylase activity and soluble protein contents. A medium without supplementing carbon source was used as control.

\section{Effect of supplementation of nitrogen source on solid state fermentation:}

The effect of supplementation of the substrate with different nitrogen sources was studied by supplementing the fermentation medium with $1 \%$ of various organic and inorganic nitrogen sources such as Peptone, Sodium nitrate, Ammonium nitrate and Ammonium sulphate . Solid state fermentation was carried out the prepared medium with initial moisture of desired level at $30^{\circ} \mathrm{c}$ for $72 \mathrm{hr}$. The samples after fermentation 
were assayed for $\alpha$-amylase activity and soluble protein contents. A medium without supplementing nitrogen source was used as the control content.

\section{Effect of inoculum size on solid state fermentation:}

A master spore suspension was made from PDA slant and varying levels of inoculums size were used. Solid state fermentation was carried out with samples that were inoculated with 1, 2, 3 and $4 \mathrm{ml}$ spore suspension. Initial moisture was adjusted to desired level; fermentation was carried out at $30^{\circ} \mathrm{c}$ for $72 \mathrm{hr}$. Sample were extracted after fermentation, and assayed for $\alpha$-amylase activity and soluble protein contents.

\section{Observation and Results}

After solid state fermentation the crude enzyme extracted was assayed for $\alpha$-amylase activity and $\alpha$ amylase activity was found to be $10.7 \mathrm{mg} / \mathrm{ml}$ and soluble protein content was found to be $18.2 \mathrm{mg} / \mathrm{ml}$.

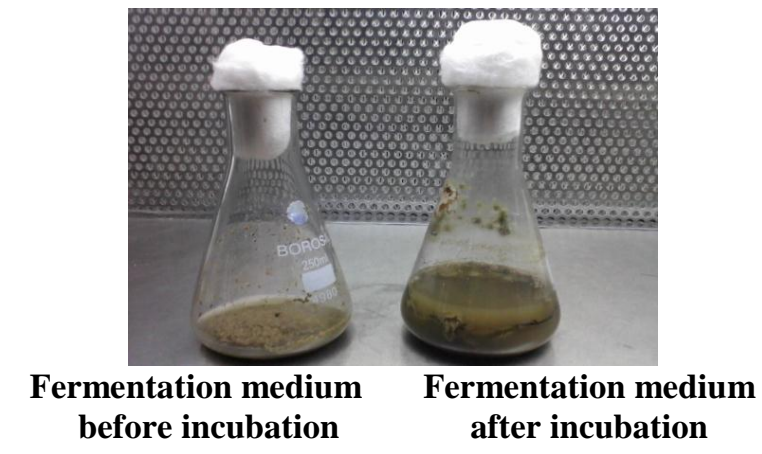

1] Effect of incubation time on solid state fermentation:

a] $\alpha$-amylase activity: The optimum enzyme activity was found after incubation time $72 \mathrm{hr}$.

\begin{tabular}{|l|l|l|}
\hline $\begin{array}{l}\text { Sr. } \\
\text { no. }\end{array}$ & $\begin{array}{l}\text { Incubation time } \\
(\mathrm{hr})\end{array}$ & $\begin{array}{l}\text { Enzyme activity } \\
(\mathrm{mg} / \mathrm{ml})\end{array}$ \\
\hline 1. & $24 \mathrm{hr}$ & 5.2 \\
\hline 2. & $48 \mathrm{hr}$ & 10.7 \\
\hline 3. & $72 \mathrm{hr}$ & 11.9 \\
\hline 4. & $96 \mathrm{hr}$ & 8.5 \\
\hline
\end{tabular}

Table no-2: enzyme activity b] Protein content by Folin Lowry method:

\begin{tabular}{|l|l|l|}
\hline $\begin{array}{l}\text { Sr. } \\
\text { no. }\end{array}$ & $\begin{array}{l}\text { Incubation time } \\
(\mathrm{hr})\end{array}$ & $\begin{array}{l}\text { Protein } \\
(\mathrm{mg} / \mathrm{ml})\end{array}$ \\
\hline 1. & $24 \mathrm{hr}$ & 9.3 \\
\hline 2. & $48 \mathrm{hr}$ & 18.2 \\
\hline 3. & $72 \mathrm{hr}$ & 20.1 \\
\hline 4. & $96 \mathrm{hr}$ & 16.7 \\
\hline
\end{tabular}

Table no -3: protein estimation

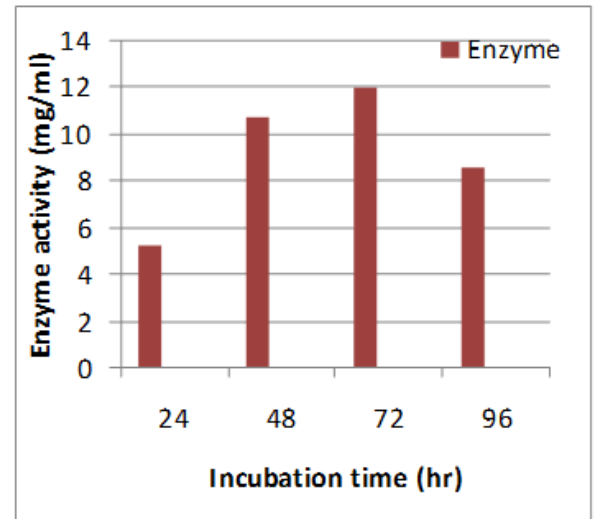

Graph-1: Effect of incubation time on enzyme activity 


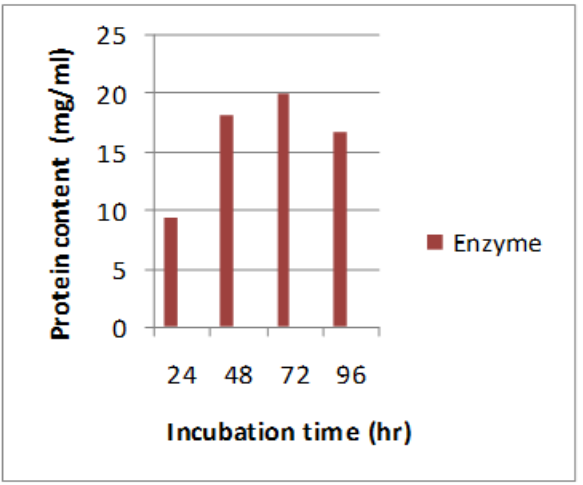

Graph-2: Effect of incubation time on protein content

2] Effect of incubation temperature on solid state fermentation: a] $\alpha$-amylase activity: The optimum enzyme activity was found at incubation temperature $30^{\circ} \mathrm{C}$.

\begin{tabular}{|l|c|l|}
\hline $\begin{array}{l}\text { Sr. } \\
\text { no. }\end{array}$ & $\begin{array}{l}\text { Incubation } \\
\text { temperature }\left({ }^{0} \mathrm{C}\right)\end{array}$ & $\begin{array}{l}\text { Enzyme activity } \\
(\mathrm{mg} / \mathrm{ml})\end{array}$ \\
\hline 1. & 20 & 3.8 \\
\hline 2. & 30 & 9.7 \\
\hline 3. & 40 & 7.3 \\
\hline 4. & 50 & 4.5 \\
\hline
\end{tabular}

Table no -4: Enzyme activity

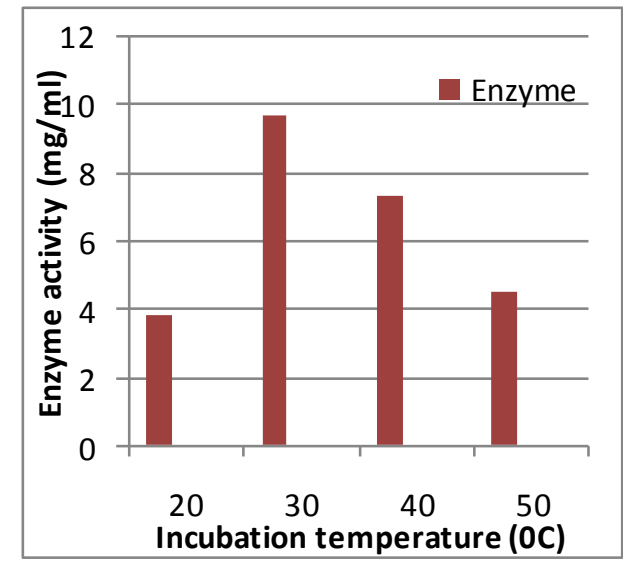

Graph-3: Effect of incubation temperature on enzyme activity b] Protein content by Folin Lowry method:

\begin{tabular}{|l|l|l|}
\hline $\begin{array}{l}\text { Sr. } \\
\text { no. }\end{array}$ & $\begin{array}{l}\text { Incubation } \\
\text { temperature }\left({ }^{0} \mathrm{C}\right)\end{array}$ & $\begin{array}{l}\text { Protein } \\
\text { content } \\
(\mathrm{mg} / \mathrm{ml})\end{array}$ \\
\hline 1. & 20 & 7.3 \\
\hline 2. & 30 & 18.2 \\
\hline 3. & 40 & 15.7 \\
\hline 4. & 50 & 8.1 \\
\hline
\end{tabular}

Table no -5: Protein estimation

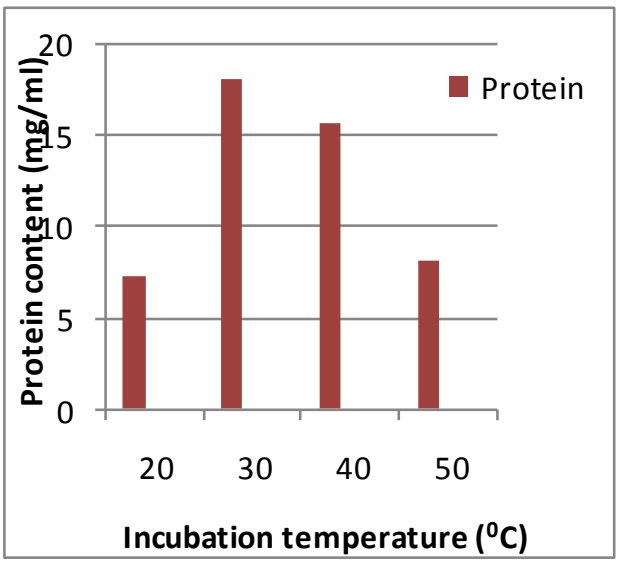

Graph 4: Effect of incubation temperature on protein estimation

Effect of supplementation of starch as additional carbon source on solid state fermentation:

[1] $\alpha$-amylase activity: The optimum activity was found at starch concentration $2 \%$.

\begin{tabular}{|c|c|c|}
\hline $\begin{array}{c}\text { Sr. } \\
\text { no. }\end{array}$ & $\begin{array}{c}\text { Soluble starch } \\
(\%)\end{array}$ & Enzyme activity (mg/ml) \\
\hline 1. & 1 & 8.5 \\
\hline 2. & 2 & 9.7 \\
\hline 3. & 3 & 5.3 \\
\hline 4. & 4 & 3.9 \\
\hline
\end{tabular}

Table no -6:enzyme activity 
[2] Protein content by Folin Lowry method:

\begin{tabular}{|l|l|l|}
\hline $\begin{array}{l}\text { Sr. } \\
\text { no. }\end{array}$ & $\begin{array}{l}\text { Soluble } \\
\text { starch }(\%)\end{array}$ & $\begin{array}{l}\text { Protein } \\
\text { content } \\
(\mathrm{mg} / \mathrm{ml})\end{array}$ \\
\hline 1. & 1 & 15.1 \\
\hline 2. & 2 & 16.3 \\
\hline 3. & 3 & 9.1 \\
\hline 4. & 4 & 5.4 \\
\hline
\end{tabular}

Table no -7: protein estimation

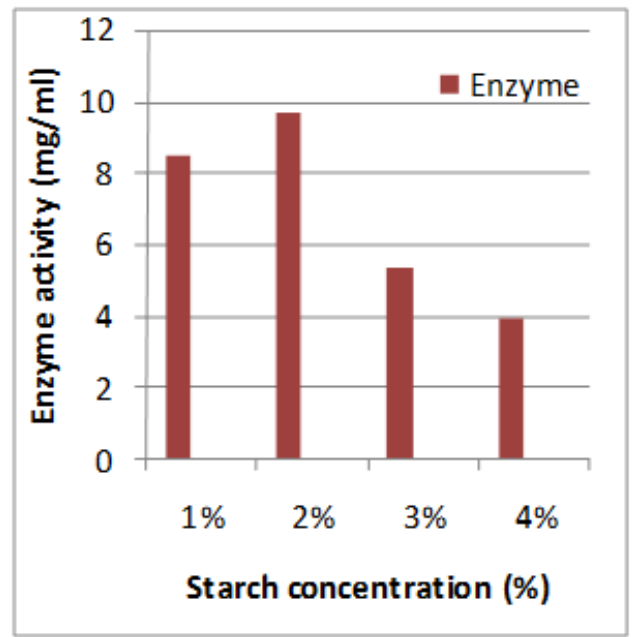

Graph-5: Effect of supplementation of starch as additional carbon source on enzyme activity

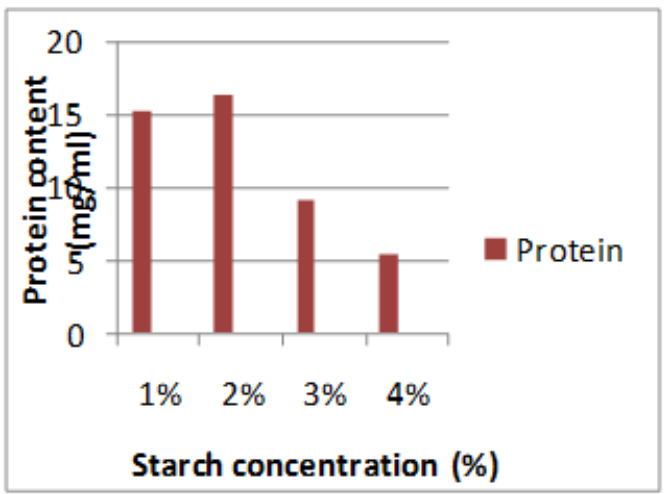

Graph-6: Effect of supplementation of starch as additional carbon source on protein content

\section{Effect of supplementation of nitrogen source on solid state fermentation:}

[1] $\alpha$-amylase activity: The optimum activity was found at nitrogen source Peptone.

\begin{tabular}{|l|c|c|}
\hline $\begin{array}{l}\text { Sr. } \\
\text { no. }\end{array}$ & Nitrogen source (\%) & $\begin{array}{c}\text { Enzyme activity } \\
(\mathrm{mg} / \mathrm{ml})\end{array}$ \\
\hline 1. & Peptone & 6.6 \\
\hline 2. & Sodium nitrate & 4.5 \\
\hline 3. & Ammonium nitrate & 3.8 \\
\hline 4. & Ammonium sulphate & 3.2 \\
\hline
\end{tabular}

Table no -8: enzyme activity

[2] Protein content by Folin Lowry method: The protein content was found at nitrogen source Peptone.

\begin{tabular}{|l|c|c|}
\hline $\begin{array}{l}\text { Sr. } \\
\text { no. }\end{array}$ & Nitrogen source $(\%)$ & $\begin{array}{c}\text { Protein content } \\
(\mathrm{mg} / \mathrm{ml})\end{array}$ \\
\hline 1. & Peptone & 10.1 \\
\hline 2. & Sodium nitrate & 7.3 \\
\hline 3. & Ammonium nitrate & 5.2 \\
\hline 4. & Ammonium sulphate & 4.8 \\
\hline
\end{tabular}

Table no -9: Proteins estimation 


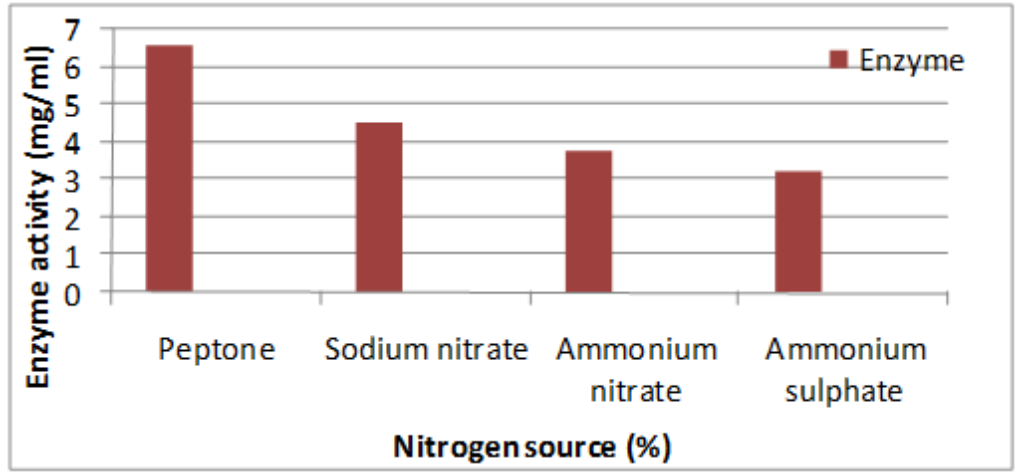

Graph-7: Effect of supplementation of nitrogen source on enzyme activity

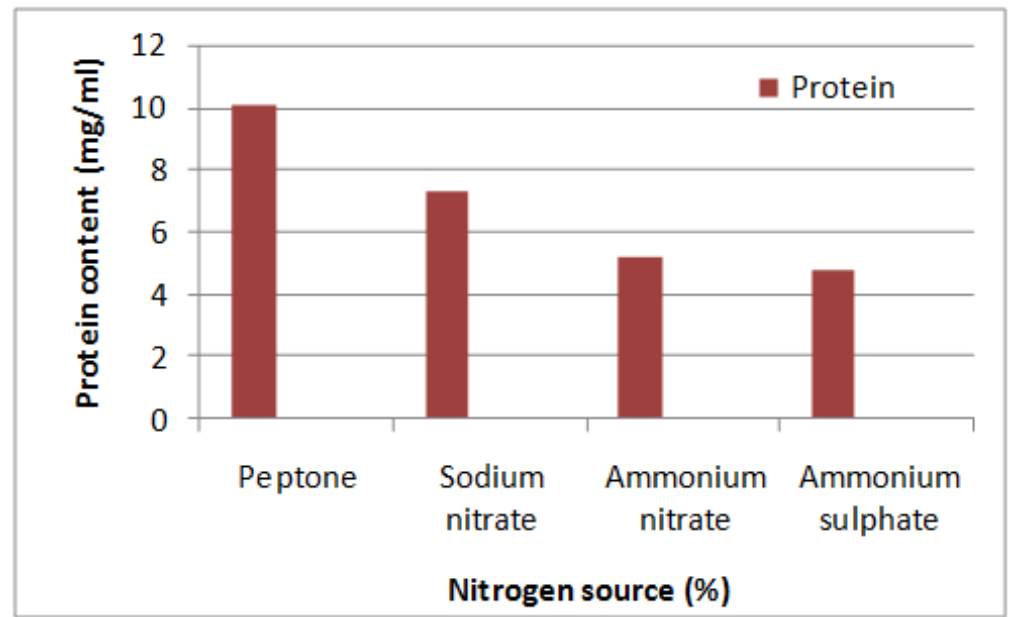

Graph-8: Effect of supplementation of nitrogen source on protein content

Effect of inoculum size on solid state fermentation:

[1] $\alpha$-amylase activity: The optimum enzyme activity was found at inoculum size $3 \mathrm{ml}$

\begin{tabular}{|c|c|c|}
\hline $\begin{array}{c}\text { Sr. } \\
\text { no. }\end{array}$ & $\begin{array}{c}\text { Inoculum size } \\
(\mathrm{ml})\end{array}$ & $\begin{array}{c}\text { Enzyme } \\
\text { activity } \\
(\mathrm{mg} / \mathrm{ml})\end{array}$ \\
\hline 1. & 1 & 7.7 \\
\hline 2. & 2 & 10.3 \\
\hline 3. & 3 & 11.4 \\
\hline 4. & 4 & 8.5 \\
\hline
\end{tabular}

Table no -10: enzyme activity

[2] Protein content by Folin Lowry method: The optimum protein content was found at inoculum size $3 \mathrm{ml}$.

\begin{tabular}{|c|c|c|}
\hline $\begin{array}{c}\text { Sr. } \\
\text { no. }\end{array}$ & $\begin{array}{c}\text { Inoculum size } \\
(\mathrm{ml})\end{array}$ & $\begin{array}{c}\text { Protein } \\
\text { content } \\
(\mathrm{mg} / \mathrm{ml})\end{array}$ \\
\hline 1. & 1 & 13.2 \\
\hline 2. & 2 & 18.3 \\
\hline 3. & 3 & 19.6 \\
\hline 4. & 4 & 15.8 \\
\hline
\end{tabular}

Table no -11: protein estimation 


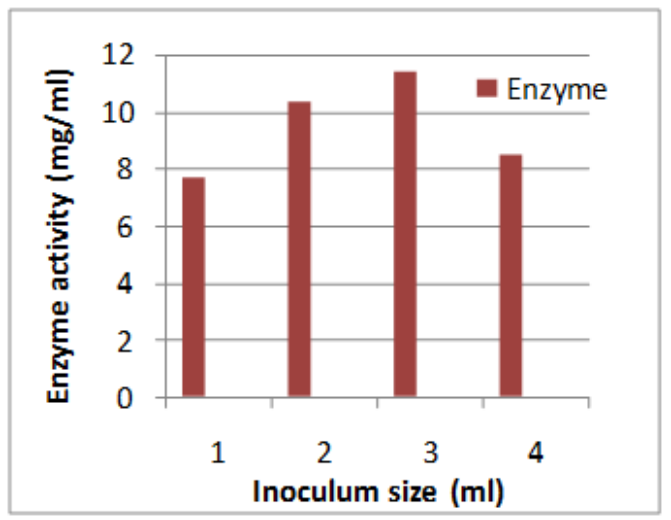

Graph-9: Effect of inoculum size on enzyme activity

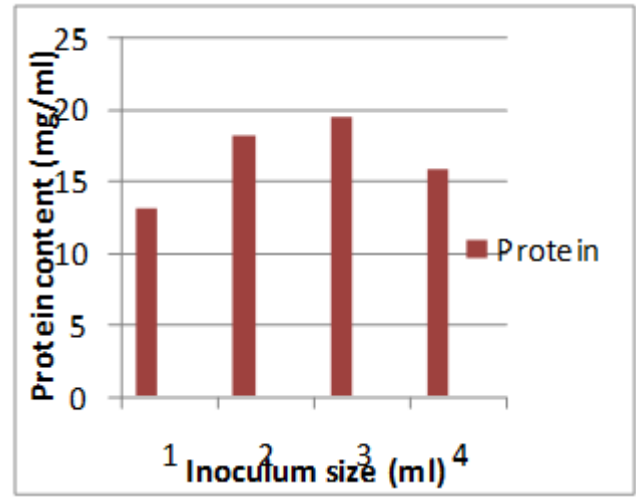

Graph-10: Effect of inoculum size on protein content

\section{Discussion}

Solid state fermentation holds tremendous potentials for the production of the enzyme amylase by Aspergillus oryzae. Oil cake especially coconut oil cake are rich source of starch. These agro industrial residues are cheap raw materials for amylase production.

Extracellular production of $\alpha$-amylase by Aspergillus oryzae under solid state fermentation using coconut oil cake as substrate was evaluated. A signal parameter approach has employed to optimize various process parameters such as incubation time, incubation temperature and inoculum size that influenced the rate of enzyme production. The effect of supplementation of substrate with additional carbon and nitrogen sources was also studied. Aspergillus oryzae was used in the present study for evaluation of its potential for $\alpha$-amylase production in which coconut oil cake is used which is an agro industrial residue. The maximum production of amylases was found to be after $72 \mathrm{hr}$ at $30^{\circ} \mathrm{C}$ and enzyme concentration at that point was $11.9 \mathrm{mg} / \mathrm{ml}$ and maximum protein content was $20.1 \mathrm{mg} / \mathrm{ml}$.

N. Uma Maheswari and S. Soundariya studied $\alpha$-amylase producing Streptomyces was isolated for the production and performed by spot inoculation method. The streptomyces isolation agar supplimented with grisofulvin $50 \mu \mathrm{g} / \mathrm{ml}$. the plate was incubated at $50^{\circ} \mathrm{C}$ after $48 \mathrm{hr}$. after incubation the plate was flooded with iodine. Zonohydrolysis of starch around the full different tested. The maximum enzyme activity was observed at $\mathrm{pH} 4$, in $\alpha$-amylase aciticity and protein content was (6.7-0.01). Amylase at among different temperature tested the maximum $\alpha$-amylase yield coconut oil cake. Enzyme activity was observed at temperature in $\alpha$-amylase (8.5-0.02) and protein content $(8.6-0.0021 \mathrm{v} / \mathrm{ml})$.

Heml Anto, Ujjval Trivedi and Kamlesh Patel worked on Bacillus species which are considered to be the most important source of $\alpha$-amylase and have been used for enzyme production using SSF. Production of $\alpha$ amylase using Bacillus cerus has been studied. Wheat bran and two waste products obtain while processing of rice to rice flakes, coarse waste and medium waste were evaluated for $\alpha$-amylase production by solid state fermentation. Among these three substrate tested highest enzyme production was observed with wheat bran (94$2 \mu / \mathrm{gm})$. Maximum enzyme production was observed after $72 \mathrm{hr}$, which decreased with further incubation. Among the two rice flake manufacturing waste tested, coarse waste gave good enzyme production and further studies are required for efficient utilization of this waste in large quantities during the rice processing.

Renato and Perez Guerralt was reported that sugarcane begasses was found to be the best substrate for amylase production by Aspergillus niger. Many reports on SSF have been published in recent years supporting the application of SSF in upgrading agricultural by products and the production of fine chemical and enzymes. 
All the substrates support the growth and enzymes production by the culture. Among them, sugar cane bagasse was found to be the best substrate for the production of amylase. All the substrate supports the growth and enzyme formation by culture. Among them sugarcane bagasses was found to be the best substrate for the production of amylase (232.65-2.74U.ml - $_{-1}$. The suitable substrate in descending order were sugarcane begasse followed by wheet bran, rice bran, black bran husk and green gram husk respectively. It was reported that sugarcane begasses was found to be the best substrate for amylase production by Aspergillus niger.

\section{Conclusion}

Oil cake have been used for feed application to poultry, fish and swine industry. Being rich in protein, some of these have also been considered ideal food for supplementation. However, with increase in emphasis on cost deduction of industrial process and value addition to agro-industrial residues, oil cake could be ideal source of proteinaceous nutrients and as support matrix for various biotechnological processes.

For the production of $\alpha$-amylase $5 \mathrm{gm}$ of solid substrate (oil cake) was taken into Erlenmeyer flask (250ml) was added with $2 \mathrm{ml}$ of mineral salt solution; add distilled water upto desired moisture level. Content of the flask were mixed and autoclaved at $121^{\circ} \mathrm{C}$ for $20 \mathrm{~min}$. Spore suspension $1 \mathrm{ml}$ of A. oryzae was used as inoculum. Incubate the flask at $30^{\circ} \mathrm{C}$ for $72 \mathrm{hr}$. After fermentation enzyme extracted and assayed for amylase and protein content.

Several oil cakes in particularly edible oil cakes of her potential benefits when utilize as substrate for bioprocess. These have been utilize for fermentative production of enzyme, antibiotics, mushrooms etc. biotechnological application of oil cakes also include their usages for vitamins and antioxidants production.

Thus it is concluded from the above study that coconut oil cake possessed good efficiency as a substrate for high yields of $\alpha$-amylase under SSF because of its high carbohydrate content, suitable texture with significant buffering capacity. Optimal for fermentation resulted in an increased in enzyme yields by A. oryzae indicating excellent capacity of fungal strain in $\alpha$-amylase production under SSF. The maximum production of amylases was found to be after $72 \mathrm{hr}$ at $30^{\circ} \mathrm{C}$ and enzyme concentration at that point was $11.9 \mathrm{mg} / \mathrm{ml}$ and maximum protein content was $20.1 \mathrm{mg} / \mathrm{ml}$.

\section{References}

[1]. Pandey A. (1990). Solid state fermentation; an overview in: solid state fermentation (Ed.) Ashok Pandey, Wiley Eastern Ltd, New Delhi, pp 3-10.

[2]. (www.seaoWndia.com).

[3]. KR Aneja, $4^{\text {th }}$ ed new age international (p) ltd, New Delhi. 2002; 161-162.

[4]. Rahardjo Y S P, Sie S, Weber F J, Tramper J and Rinzema A, Effect of low oxygen concentration on growth and alpha-amylase production of Aspergillus oryzae in model solid state fermentation system, Biomol Eng, 21 (2005)163-172.

[5]. Wolfgang A. Enzyme in Indus try: Production and Applications. Wiley- VCH, Weinheim; 2007.

[6]. Akpan I, Bankjole MO, Adesermowo AM and Lantumde- Data. Production of $\alpha$ - amylase by Aspergillus niger in a cheap solid medium using rice bran and agricultural material. Trop. Sci 1999; 39; 77-79.

[7]. Nandakumar M P, Thakur M S, Raghavarao K S M S and Ghildyal N P, Studies on catabolite repression in solid- state fermentation for biosynthesis of fungal amylases, Lett Appl Microbial, 29 (1999) 380-384.

[8]. Rahardjo Y S P, Sie S, Weber F J, Tramper J and Rinzema A, Effect of low oxygen concentration on growth and alpha-amylase production of Aspergillus oryzae in model solid state fermentation system, Biomol Eng, 21 (2005)163-172.

[9]. Singh, K.; Garg, S.K.; Kalla, A. and Bhatnagar, A. (2003), Oilcakes as protein sources in supplementary diets for the growth of Cirrhinus mrigala (Ham.) fingerlings: laboratory and fields studies. Bio resource technology., 86, 283-291.

[10]. Pandey, A. Soccol, C.R.; Nigam, P.; and Soccol, V.T. (2000), Biotechnological potential of agro-industrial recidues, I: Sugarcane baggase, Bioresource technology, 74, 69-80.

[11]. Pandey, A.; Soccol, C.R.; Rodriguez, L.J. and Nigam, P. (2001) Solid-state Fermentation in biotechnology., New Delhi : Asiatech Publishers. pp. 221.

[12]. Benjamin, S. and Pandey, A. (1997), Coconut cake: A potent substrate for production of lipase by Candida rugosa in solid- state fermentation. Acta Biotechnol., 17, 241-251.

[13]. Benjamin, S. and Pandey, A. (1998), Mixed solid substrate fermentation: A novel process for enhanced lipase production by Candida rugosa. Acta Biotechnol., 18, 315-324.

[14]. Bennett JW (2010) “An Overview of the Genus Aspergillus". Aspergillus: Molecular Biology and Genomics. Caister Academic Press. ISBN 978-1-904455-53-0.

[15]. Wortman; Gilsenan, J,; Joardar, V.; Deegan, J,; Clutterbuck, j.; Andersen, M.; Archer, D.; Bencina, M. et al. (2009). "The 2008 update of the Aspergillus nidulans genome annotation: a community effort". Fungal genetics and biology: FG and B 46 Suppl 1: S213. Doi: 10.1016/j.fgb.2008.12.003. 